\title{
Multiple Possibilities: The Multi-literate Lives of Three Children
}

\author{
JEFFREY WOOD \\ Laurentian University (Canada)
}

\begin{abstract}
This paper presents findings from an eleven-year ethnographic study which describes how three children used different sign systems to become literate, to define who they are and to construct their literate identity. They each engaged with literacies in powerful and life transforming ways. Each child used multiple literacies to learn, understand and create meaning more fully, and use their motivated interest in a preferred literacy to scaffold their learning of another.

In analysing this rich literacies use, I have come to understand that literacies are complex in their conception and use and that all sign systems (e.g. art, dance, reading, writing, videogaming, etc.) operate using common semiotic principles. Sign systems as literacies are multimodal, meaningfocused and motivated; they involve specific social and cultural practices which differ depending on site and community. During every literate act the children in this study made extensive use of the semantic, sensory, syntactic and pragmatic cuing systems to make meaning, regardless of the literacies used.
\end{abstract}

\section{Multiple Possibilities: The Multi-literate Lives of Three Children}

Children use literacies in complex and multiple ways. The use of 21st century literacies has changed how children, and adults, use literacies, and has changed what is possible. These new literacies have reshaped our understanding of who we are as literate beings, both through the use of new literacies and through how we use and understand old literacies. We no longer think of literacy as singular and monolithic but as literacies, something that is multiple and fluid. This paper comes out of an eleven year ethnographic parent research study conducted from 1995 to 2006 which looks at the 
literacies use and understanding of my three children during that time, and shares what they taught me about literacies.

In her keynote address to the Researching and Teaching in These Critical Times conference, Debbie Rowe stated:

Future research needs to record literacy activities in infant, toddler, and younger preschoolers' homes and childcare settings - whether or not they are intended as opportunities for children to read or write. Ideally, early literacy research would begin to describe cross-contextual patterns and variation in these youngest children's access to observing and participating in literacy events, as well as caregiver beliefs and values about early literacy experiences. (2005, p.5)

Rowe went on to describe the need for an expanded research agenda into early literacy and that we need to use an expanded theoretical lens for understanding children's early literacy participation. I have done just this in my research. For the time included in this study I collected data on my three children's literacies uses and understandings across various settings, including our home and other sites. I observed and collected data from my children in an attempt to better understand literacy, and my children, as a parent, a researcher and a teacher. In light of Debbie Rowe's call for a renewed emphasis on early literacy and her description of the need to understand children's participation with literacies I felt it was important to go back and reanalyze what my children have taught me.

This research is an attempt to look at Emily, Tristan, and Simon historically and holistically. I have tried to reveal and explain their literacies uses and understandings over time and across contexts while treating literacies as a complex process. I approach literacies as 1) multimodal, semiotic and motivated; 2) involving specific social and cultural practices, while also recognizing that these practices are different depending on site, community, and time; and 3) as social.

\section{Procedures}

In this ethnographic study I took a qualitative approach to the data collection and analysis. As I was primarily interested in the children's uses and understandings of literacy, this seemed the logical approach to take. It afforded me the opportunity to analyze across use, learning, development, purpose, and function in ways that a quantitative study would not allow. Added to this, I wanted this study to be as nonintrusive as possible. As such, I conducted it from a naturalistic, ethnographic perspective, taking the stance of an involved participant in my children's literacies uses and understandings. I collected their instances of literacies or literacies events (Heath, 1983, p. 93), whenever possible, and analyzed them on an ongoing basis for changes in use or indications that their understanding about literacies had changed. These are both above and beyond the regular formal and informal observations recorded about book handling, book choice, mathematics use, dramatic play, and other literacies events (Hamilton, 2000, p.18) that occurred on a daily basis. 


\section{Parent as Researcher.}

As a parent researcher I have tremendous access to the site, contexts, cultures, and systems of the participants in the study. I also have a tremendous amount of access to the participants themselves and not just in one setting but in the complex multiple settings in which we all live our lives. This allows me as a researcher more of a full picture-to see the complexities of literacies that an objective observer will never see, will never gain access to. Therefore, as a parent researcher I have intimate access and details about the child as a language and literacies user.

This intimacy brings with it difficulty as well. It subjects the researcher, unnecessarily, to questions of objectivity and bias. My response then to this is quite simple: of course a parent will always be an advocate for their child - if they were not, we would question whether they were a good parent.I would argue, as do Denzin (1997), Carspecken (1996), and Lather (1992) that the objective observer, too, is biased, and is generally a person who embraces their subjects just as passionately as the parent does their own child. The difference is that for the parent this relationship is transparent, obvious and revealed, where for the clinical observer this passion is veiled by procedure, objectivity, and verisimilitude.

Research into the literacies use/development of children by their own parents has a long tradition, the most notable researcher being Jean Piaget (1971). Many parent researchers have had significant influence in the field of literacies research: Marcia Baghban (1984, 2002), Glenda Bissex (1980), David Doake (1988), James Gee (2003), Jerry Harste et. al. (1984), Prisca Martens (1996), Judith Schickedanz (1990), and Patrick Shannon (1995) have all studied their own children.

As a parent researcher I am hopelessly entangled with the subject matter and my participants, we cannot be separated, and the search for understanding and truth is slippery (Britzman, 1997). Yet this is not a weakness but a strength of this research and when laid bare, as I have done, it leaves the reader to decide whether a statement is the result of a parent's love, a researcher's objective observation, or if it really matters in the end.

\section{Data collection.}

For each of my children the corpus of data was different in quantity, quality and time. For Emily, who was born in February 1993, I have the greatest amount of raw data; this is because she has been the most interested in traditional literacy (i.e., reading and writing) of all my children, and also because I studied her work the longest. However, my earlier interest in her work was focused on writing development, so the data I have before 1998 is focused primarily on writing and is coloured by the lens of development something Emily taught me does not do a good job of describing her learning and literacies uses. Thus, although Emily's data was the greatest in quantity, the quality of the earliest data is limited. For Tristan, who was born in May 1996, the data quantity was less, primarily because he showed less interest in traditional literacies than Emily. I also did not recognize Tristan's literacies use and learning until 1998, because his use was 
different from that of Emily and was not focused on writing but was focused more on maths and games. I also did not believe that children engaged in literacies use until they were at least two years old. However, when I did take notice of Tristan's literacies use I collected a broader spectrum and had the knowledge of what Emily had taught me to help me see more and be more accepting in what I considered data and literacies. Simon, who was born in December 1998, has the least amount of data, primarily because of the timeline of this study, but his data was the richest. What I considered literacies use and learning data was considerably broader with Simon than with Tristan and Emily. Simon is a natural storyteller, and he regularly verbalized what he was thinking, giving insight into literacies learning which was far richer than was possible with either Emily or Tristan (for a visual timeline please see table 1).

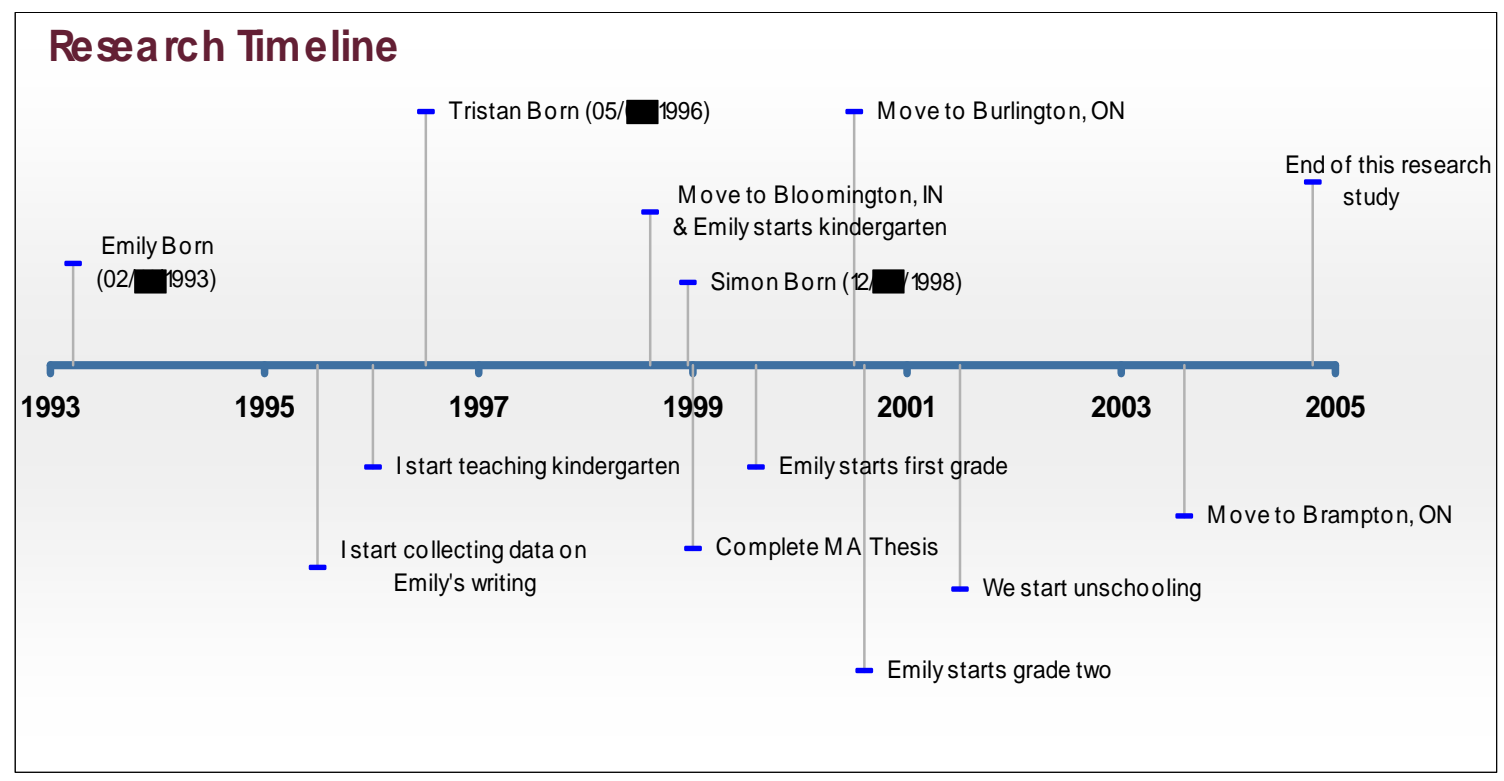

Table 1- Research Timeline

\section{Data analysis.}

My analysis of the data was comprised of basic category generation (Creswell, 1994) and a form of initial meaning reconstruction (Carspecken, 1996). All the data was analyzed through the lens of initial meaning analysis to construct basic categories and to find anomalies. These initial categories were then developed into matrices (Creswell, 1994) to further analyze the relationships among categories; the information was coded across categories by child, site, time (both chronological and age), purpose, social setting, context, and other delineators that arose during analysis and were more specific to each of the individual children/literacy. From this analysis I then selected what I felt were representative stories that exemplified what I was learning from the children and represented how they understood and used literacies. 


\section{Literacies as Complex Systems}

Literacies are irreducibly complex and to understand them the interactions among the subunits, or cueing systems and other factors which influence literacies, must be taken into account as a whole. When we think of literacies as a complex system, the analysis of any one of the subset systems will give little information about or allow reproduction of the system because the patterns, or in this case meanings, are only created in the interaction between subsystems.

Those processes are characterized by simple "rules" that depend solely on local interactions among the subunits of the system. Yet despite their simplicity and the local range of their immediate effects, the rules and their actions on the subunits give rise to the spontaneous emergence of pattern, order, and structure on a global, system-wide scale. The patterns that arise are emergent properties, properties that cannot be predicted simply by examining the subunits in isolation. To understand them, the dynamic and often remarkably complex interactions among the subunits must be taken into account (Camazine, 2003, p.39).

I have come to a better understanding of literacies through the use of complex systems to help me understand how my children are learning, using and understanding literacies. In attempting to analyze the whole of literacies for my children I was able to see the complex interactions among its subunits and better understand literacies as a process. We need to think of literacies as complex while simultaneously treating them as multimodal, semiotic, social, discourse dependant, and imbedded in specific practices.

\section{Some Background}

Learning has come hard for me during this inquiry. I always thought I had the answers, and I thought I knew what I was looking for. As adults we rarely take the time to truly listen to each other and even less so to the children around us: the children we teach, and the children we develop curriculum and theory for. The work we do as teachers and researchers we presuppose is for the betterment of the children we work with, yet how often do we really look at what they are doing or stop to really listen to what they are saying? We think we have the answers and we know how to help the children we are working with, but more often than not we do not.

I do not mean to say that everyone is like me; I have had the privilege of working with several educators who really listen to children and try to learn from them, but they are in the minority. These educators patiently taught me the importance of seeing and listening, and then they taught me how to learn from what I saw, heard and experienced. We need to take the time to learn from children because they are far wiser and more intelligent than we can ever imagine. Children will show us what we need to know to help them, if we are willing to listen. Children have the answers to our questions; we only need to enter their world as learners, not experts.

Throughout this research I started to leave the world of adults, and our important business, and enter the world of children; and to understand fully what children have been telling me. The children who have been my greatest informants are my own 
children, for they are the only ones willing to put up with my blunderings and misunderstandings for so long. It is as if young children are aware that grown-ups just do not understand, but are willing to explain what they are thinking and doing, when we, as adults, are willing to listen. We must learn the language of children and become fluent-a fluency I am still developing. We must forget about what we think is important and how we think things work, and begin to listen and learn from the children who are our informants. Then and only then will we understand the complex ways children view literacies and how they use them in meaningful ways.

I am certain that what I am learning now is still being influenced by my tacit assumptions but I have had the opportunity to interrogate many of these assumptions and drag them into the light of what children have been teaching me (see table 2).

\begin{tabular}{|l|l|}
\hline \multicolumn{1}{|c|}{ Past Assumptions } & \multicolumn{1}{c|}{ Current Assumptions } \\
\hline $\begin{array}{l}\text { Learning literacy is largely a factor of } \\
\text { maturation }\end{array}$ & $\begin{array}{l}\text { Learning literacies is a matter of } \\
\text { experience }\end{array}$ \\
\hline Literacy is reading and writing & $\begin{array}{l}\text { Literacies are multiple and are any } \\
\text { meaning making sign system }\end{array}$ \\
\hline $\begin{array}{l}\text { Sign systems are a support for literacy } \\
\text { learning }\end{array}$ & Sign systems are literacies \\
\hline $\begin{array}{l}\text { Learners go through specific stages of } \\
\text { literacy development }\end{array}$ & $\begin{array}{l}\text { Literacies users entertain multiple } \\
\text { hypotheses about literacies at any } \\
\text { given time }\end{array}$ \\
\hline $\begin{array}{l}\text { Conventional literacy is the measure } \\
\text { of success }\end{array}$ & $\begin{array}{l}\text { The richness of the ideas being } \\
\text { expressed with a literacy is what is } \\
\text { most important }\end{array}$ \\
\hline $\begin{array}{l}\text { Literacy is something that takes place } \\
\text { primarily in the head }\end{array}$ & $\begin{array}{l}\text { Literacies are primarily social and } \\
\text { cultural practices }\end{array}$ \\
\hline
\end{tabular}

Table 2: Some of my key past and current assumption about literacies

\section{Learning from Children}

Grown-ups never understand anything by themselves, and it is exhausting for children to have to provide explanations over and over again. (de Saint-Exupéry, 1943, p.4)

I have been transformed by what children have been patient enough to teach me; it has affected my teaching and the way I approach literacies and learning. I believe that we need to reconsider our research model when we go into a classroom or interview children about our preconceived notions of literacies and presuppose that it is our job to teach them to be literate through some better method. Children are the reason we do the work we do; we want to help them better integrate into our societal discourse, of which a large part is reading, writing and using other literacies in very specific ways. It seems obvious to me then that we would want to understand what literacies are to children 
and to take time to observe and understand how they use them, and I am not alone in this belief (e.g., Gallas, 1998; Paley, 1999; Paley, 2000; Taylor, 1993; Vasquez, 2004).

We need to think about learning as a continuum and not an end point to be achieved. We are immersed in literacies, like fish in water; it is just that it is so much part of our lives we rarely take time to notice, and when we do it is difficult to see and understand. We are all, including children, immersed in literacies that we have to use daily to make sense of the world around us. If we take the time to learn from children we can understand their literacies and we can better understand how to support all literacies. Learning from children is essential to bettering our understanding of literacies and how children learn in general. We need to view children as our informants and not as our subjects.

\section{Emily, Tristan and Simon's Literacies Use}

In documenting how Emily, Tristan and Simon have used literacies, both singly and, more importantly, as multiple literacies, I have gained insight not only into how the literacies process works, but also into how the children have each used literacies to support their own learning, through taking what they knew in one literacy and applying it to another; scaffolding their own learning (Vygotsky, 1978). Through this research I have come to redefine literacies and even what I consider as literacy. Emily, Tristan and Simon have helped me to see that literacies are complex in their conception and use and that all sign systems have the same underlying process and should be considered literacies. They have helped me see literacies as: multimodal, semiotic and motivated; social, and embedded within multiple layers of discourses; and involving specific social and cultural practices which are different depending on site and community.

Emily, Tristan and Simon also taught me that we need to see children as literate, and value their literacies learning. All children are symbol users and make meaning from and in our society. They are strong, rich, powerful, and capable literacies users. It is up to us to recognize this and support their learning. To summarize what I have learned from Emily, Tristan and Simon and to discuss my new understanding of literacies I have chosen to relate one story from each of their experiences.

\section{Emily's use of dance to become a precocious reader.}

To illustrate Emily's experience, I would like to share how during first grade she went from being an average first grade reader to becoming a precocious reader. There were two significant influences that pushed her reading from grade level expectations, reading supported text in picture books, and turned her into a proficient reader, and someone who identified herself as a reader. The first significant factor was Emily's interest in dance, specifically the Nutcracker ballet. Emily was enamored with The Nutcracker and decided to coordinate a performance of this ballet with her friends. At first Emily listened to the music and watched videos of The Nutcracker. We talked to a friend of ours, who happened to be a senior in dance performance at university, about 
Emily's interest in The Nutcracker. Julia ${ }^{1}$ volunteered to help Emily learn some of the dance steps and came by our house once a week to work with her. Emily was also enrolled in movement classes at a local dance studio. Julia later invited Emily to see her performance of The Nutcracker and invited her backstage (see figure 1). Afterwards Julia gave Emily the ballet shoes she wore in the performance. Emily was ecstatic. This event motivated Emily's interest in dance and The Nutcracker to a fever pitch. She quickly exhausted the library of age appropriate ballet books and videos and started to borrow coffee table books from the adult section of the library. She started to take an interest in the lives of ballet dancers when Liz (another friend of ours involved in ballet) gave her a copy of On Stage Please by Veronica Tennant (1979) for her birthday in February. I still remember my astonishment when I saw Emily return from the library with a huge book on the life of Baryshnikov; the book was almost as large as she was. All the while Emily continued to

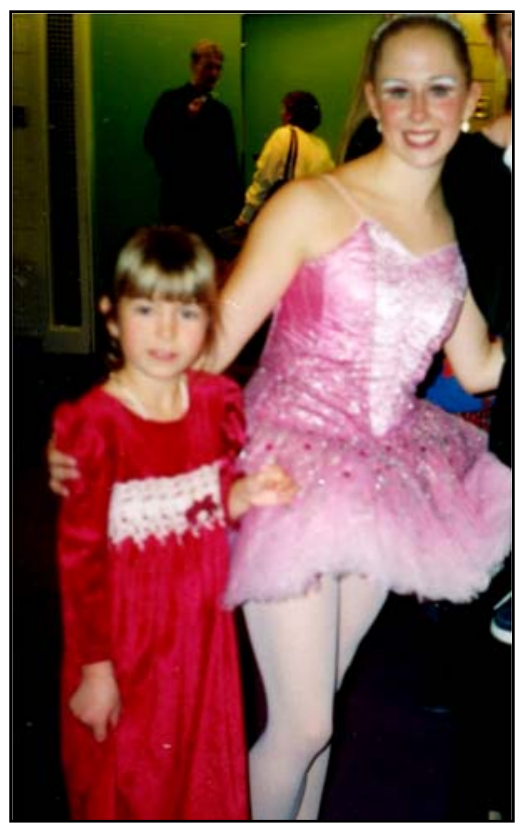

Figure 1: Emily and Julia after The Nutcracker (age 6) practice dancing the dance of the snow fairies from The Nutcracker. In April, because it had not worked out for any of Emily's friends to take part in her project, Julia arranged for her friends in the dance program to fill in. Emily hand

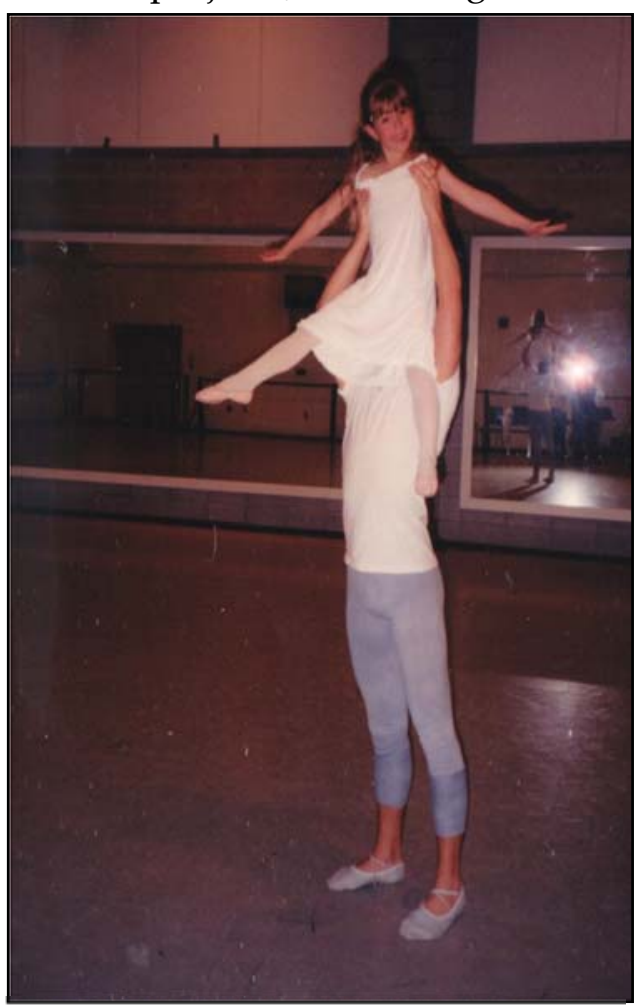

Figure 2: Emily dancing the part of Clara in The Nutcracker (age 6) wrote invitations for family members and friends to attend the performance. And at the beginning of May Emily danced the dance of the snow fairies at the university practice studio (see figure 2).

Emily's reading ability grew in leaps and bounds during this time largely because of her intense interest in ballet, specifically The Nutcracker. Her reading excelled so that there was nothing she could not read and by the spring Emily was reading Little Women (Alcott, 1995/1868). She used music, video, dance, talk, reading and writing to navigate through this experience. At every turn she used her prior knowledge and supports from multiple literacies to support her reading. All of these literacies worked together to complement and scaffold each other in Emily's literacies learning. Emily's reading improved because of her motivated reading of dance related material and her reading worked to support and improve her dance.

${ }^{1}$ All the names in this paper that do not belong to immediate family are pseudonyms. 
Upon closer analysis another significant thread emerged. That year at school her teachers, Mr. V and Ms. E, were exploring the use of a critical literacies framework (Vasquez, 2004; Luke \& Freebody, 1997) to guide language arts instruction and practice in the classroom. The students had been introduced to critical literacy circles when they met with their fifth grade reading buddies; I helped lead one as a parent volunteer on a weekly basis. During these times we read books dealing with critical issues like those found in Sister Anne's Hands (Lorbiecki \& Popp, 1998), Amazing Grace (Hoffman, 1991), Voices in the Park (Browne, 1998), White Socks Only (Colman, 1996), Whitewash (Shange, 1997), Just One Flick of a Finger (Lorbiecki, 1996), etc. We used these books as touchstones for discussions with the students and made explicit connections between the books and the lived experiences of the students. The students regularly engaged in written response to the text we read and we would often use strategies like sketch to stretch (Short, Harste, and Burke, 1996). On several occasions the students dramatized a critical or significant scene from one of the books we were reading.

Through her experiences in this class Emily saw literacies as something that was related to her life and could be used to explore issues and feelings she was having. Books were real and meaningful in this class; they dealt with issues like racism, poverty, and other issues that affected the children's lives (for further examples of how this class used critical literacy texts see Wood, 2002). The students in this class became familiar with using books to discuss serious issues and using literacy in significant ways that affected their lives. Literacies were used as meaningful and powerful shapers of the children's lives. It was this powerful teaching, melded with Emily's own passion for dance, that motivated her to excel in her reading and to see reading, dance and writing as ways to explore and critically influence her world. It was her intense interest in these literacies that allowed her to use each of them to support her learning of reading, dance and writing and become precocious at each.

Tristan's use of videogaming to become a reader.

To illustrate Tristan's journey I will share how he used videogaming as a literate experience, and as a catalyst to becoming a reader and seeing himself as a reader. For a long time Tristan saw the reading which Emily, Christine ${ }^{2}$ and I were doing (the reading of novels, newspapers and magazines, etc.) as "real reading"; he saw his own reading of street signs and pictures books as less than reading. The key event to Tristan's becoming a reader and a full member of the 'literacy club' took place after he received a Nintendo Game Boy Color as a Christmas gift when he was seven (see figure 3). He quickly became bored with Tetris, the game his Gameboy came with, and wanted to buy a new game. Tristan and I researched together where to buy games, how much they cost, and which games were recommended by others for the Gameboy.

Tristan decided to buy a used version of Super Mario Bros. Deluxe (Nintendo, 1999), a game developed specifically to sell his type of Gameboy, and one which seemed universally recommended, with his birthday money. Tristan began playing Mario

\footnotetext{
${ }^{2}$ Christine is the children's mother
} 
Brothers immediately after getting the game home, but he quickly became frustrated, as the used game did not come with an instruction manual and he could only figure out so much through game play on his own. To help him I went online with Tristan and we found several FAQ sheets and walkthroughs for the game (see figure 4). I printed the ones I thought were most useful but it was past his bedtime so I put them aside, intending to go through them with him when I came home from work the next day. He was now eight years old and still did not see himself as a reader and I did not think he would read the FAQs on his own. But Tristan found the FAQ sheets and walkthroughs the next morning and immediately began reading them, even though they were dense with text and were single spaced pages printed in 10 point courier (see figure 4). He used what he learned in the FAQ sheet and immediately started playing the game.

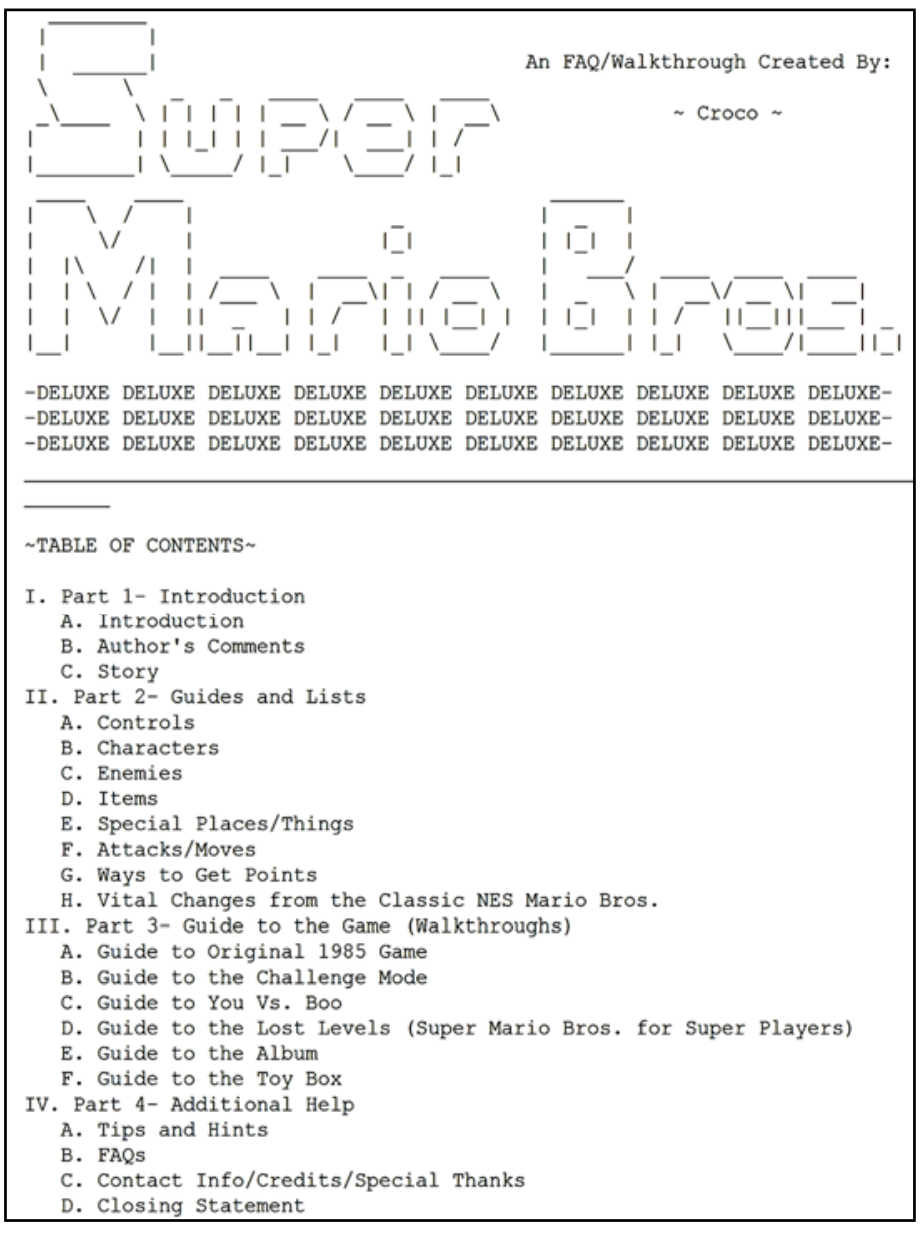

Figure 4: The cover page of the FAQ Tristan used to play Super Mario Bros.

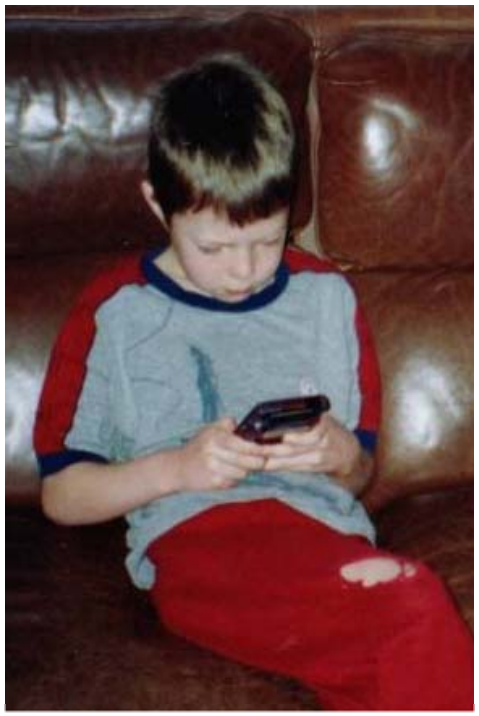

Figure 3: Tristan playing his Game Boy Color (age 8)

When I arrived home that evening Tristan showed me how far he had advanced in Mario Brothers; he showed me the FAQ and told me what he had learned. Christine and I praised his work and his reading. Tristan glowed. That night when he went to bed he decided to read a chapter book. After he went to bed Christine told me how he sat down and read through the FAQ on his own, intently focused for half an hour. This one small thing was the final piece in bringing Tristan to where he could see himself as a reader and join the literacy club. This is by no means how he learned to read, but was the key to helping him get over the hurdle of text size and knowing for himself that he could read text which was unsupported by pictures immediately on the page.

Tristan's experience with videogaming as a literate activity, 
combined with his past experiences with reading and his desire to figure out how to play Super Mario Brothers Deluxe on his own, allowed him to successfully access the text and read the FAQ. He was highly motivated and had the ability to verify the meaning he read from the FAQ with his game play. These elements worked together to help Tristan see himself as a reader and to create meaning from the FAQ in a useful manner. Within a month Tristan was reading The Hobbit by Tolkien (1937/1999). Tristan now reads anything he can put his hands on. But this was not a one way transaction; Tristan used his ability as a reader to improve his videogaming and, specifically, to learn how to play Super Mario Brothers Deluxe. These literacies worked together to support Tristan's learning, use and understanding in each.

Simon's use of comics as a path to writing.

To illustrate Simon's story I want to share how he used his interest in and passion for drawing as a way of accessing the more traditional literacies of reading and writing, through making comic books. Simon loves writing, drawing and building with Lego and sees all of these as literacies. For Simon literacies have always been about meaning making. But it was the world of art and drawing that he used to create meaning and understand the world. His art has always been social in its conception and use, and his production of comic books was no different. Simon was very familiar with and enjoyed the genre of comics. Tristan and Emily would read to him from DC Junior Comics, and other comics and cartoons. He had also seen Emily and Tristan collaborate on several comics and had started to experiment with making his own comic books.

Spy Dog evolved when Simon was five years old. Tristan and Simon were writing together; Tristan was writing a book called Spys and Simon copied him, to which Tristan complained, so Simon changed the title of his story to Spy Dog, combining his interest in dogs and superheroes. Spy Dog (see figure 5) consumed Simon's writing through to the end of my study and would include no less than six volumes; one of these comic books, Spy Dog 4, is over one hundred pages long. Outside of the sheer volume and time involved in the production of the Spy Dog comics, it was a place where Simon started to explore conventional spellings (see figure 6). Initially, in Spy Dog 1, Simon asked Tristan to help with the generation of the text, but in subsequent comic books he would only occasionally ask how to spell a word, and more often he would just apply what he thought was correct. Simon incorporated his experience with multiple literacies to create meaning in his comics. He used his experiences with videogaming, Lego, and the Lego website to construct the design of his images and the structure of his comic books (see figure 6). He incorporated elements which he found in the comic books that he read and which were read to him (e.g., dialogue bubbles, panels, gutters, thought bubbles, etc.). He used all of these literacies together, not only to powerfully create meaning in his comic books, but also to support his meaning making, drawing on what he knew from these literacies to expand what he was capable of with writing on its own. He was intimately aware of this literacies use, stating, as he worked on a Spy Dog comic: "I love that I can learn to read and write at the same time." 


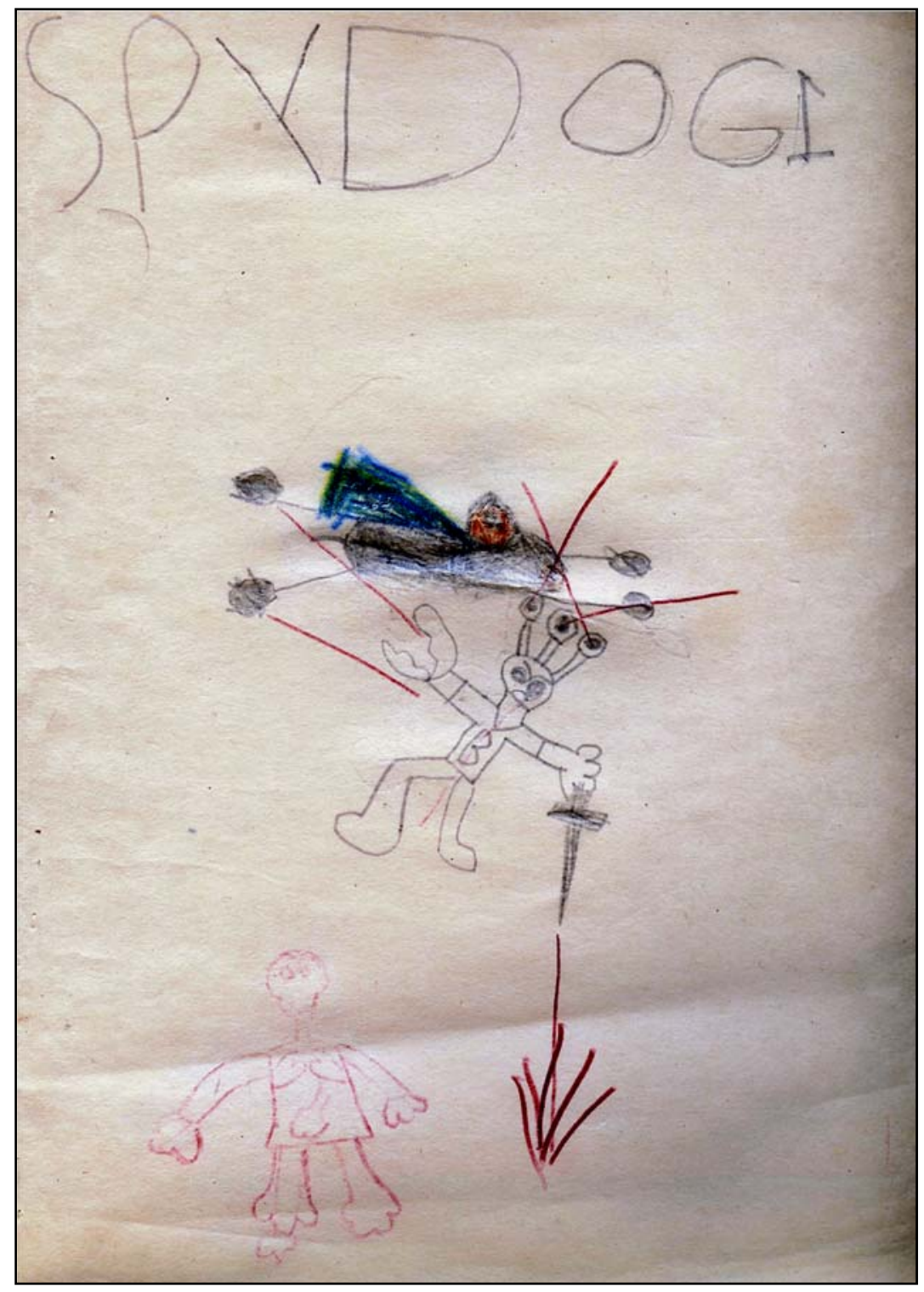

Figure 5: Cover of Spy Dog 1 (age 5)

Reading was a struggle for Simon; although he was an early reader, reading Freight Train (Crews, 1978) when he was two and half years old, by the time he was five years old he did not see himself as a reader. When Simon read books he was wholly focused on his own meaning creation; so focused was he on creating meaning for himself that he ignored the author's message. Simon was a 'universal reader' (Phinney, 1988). And by the time he was five he knew that he was not able to access books without pictures. He did not see himself as a member of the literacy club and avoided books at all cost.

Through Spy Dog Simon slowly started to make a connection between his art and writing, to create meaning that could be understood by others, and a connection between his writing and reading so that he could understand text created by others. He transferred the knowledge he was using to create his comic books to scaffold his reading. Simon became enthused by the works of Bill Watterson, Gary Larson and Jim 


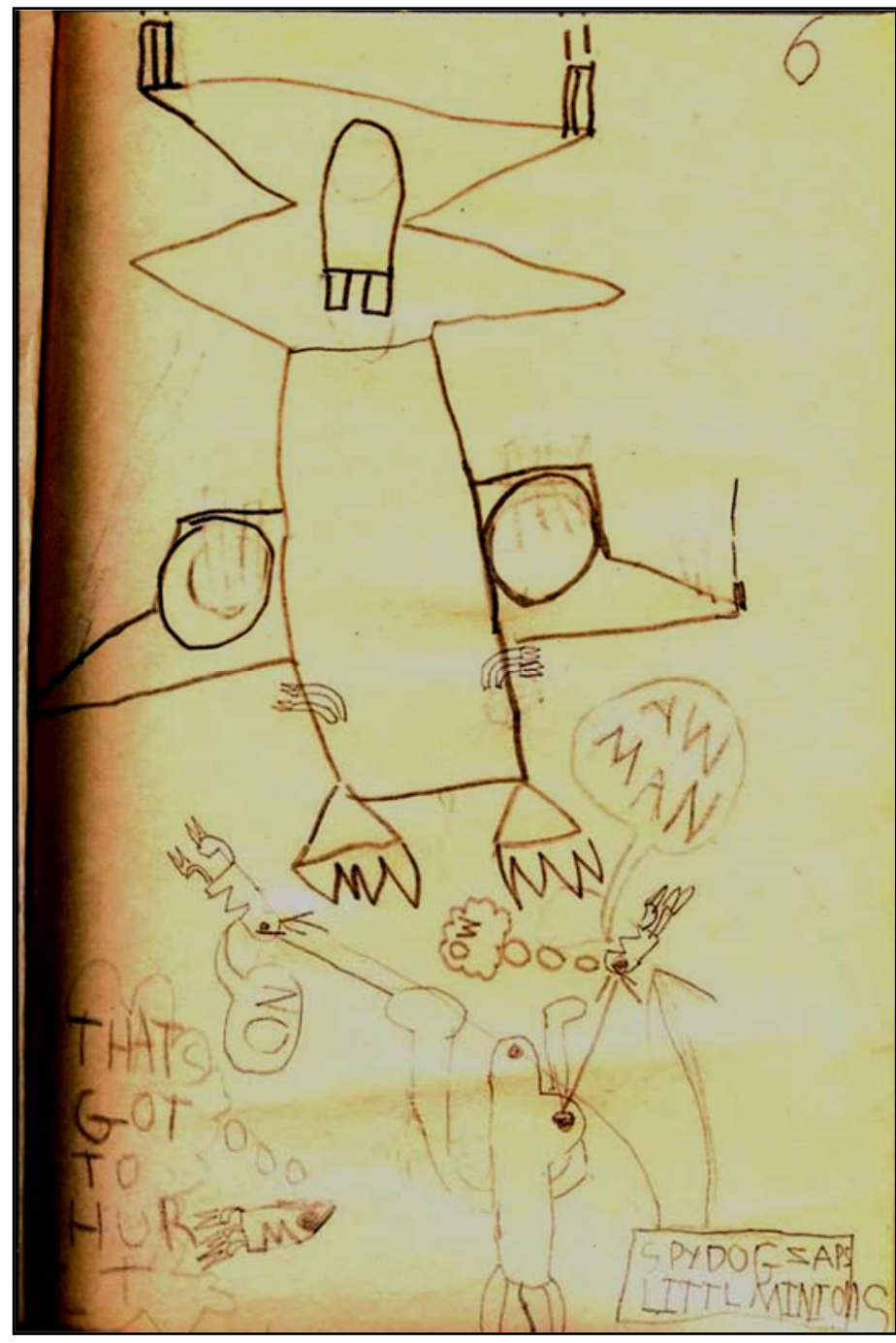

proficient in all three.
Davis. He started reading books about hockey and at the age of eight he purchased and then read The Arabian Nights (Lowe, 1924).

Spy Dog was a breakthrough for Simon; it was here that he was able to establish himself as an individual within our family. Comic book creation was one thing that he was better at than anyone in the whole family. He was able to combine his love of drawing and writing to convey meaning in a powerful and entertaining way. It was this intense interest and focus on comic books that helped Simon focus on the details in the books he read and gave him access to the text. Simon used his interest and understanding of drawing to scaffold his understanding of writing to scaffold his understanding of reading. He used all three literacies to support each other, becoming

\section{Literacies Model}

To help me make sense of how the children were using literacies I worked on developing a model that would explain what they were doing and would help to clarify my own thinking. I started by building on Ken Goodman's (1967) reading model because I think it does a good job of describing what the children were doing with reading and how reading works as a literacy. But I used the expanded model suggested by Harste, Woodward \& Burke (1984) because of their inclusion of pragmatics (see figure 7). Through my research with my children I have come to understand literacies as a complex system, and I see literacies as multiple, created, and used through a critical sociopsychosemiotic process (Wood, (Wood, 2002). Literacies are ultimately semiotic in that they use signs to convey meaning or are symbolic in nature (Danesi, 1998; 2004). They are multimodal. All literacies: art, dance, language, etc., use similar underlying systems in their meaning making. It is this similarity between these underlying processes that makes literacies use, understanding, and learning multimodal. During 
every literate act the literacies user uses four cueing systems to make meaning: semantic, sensory, syntactic and pragmatic (see figure 8), and it is in the interactions between these subsystems that meaning is actively created.

At the heart of the literacies process is semantics, or meaning making, though all the cueing systems also work together to make meaning from literacies. At its simplest, semantics is meaning making; the meaning derived from

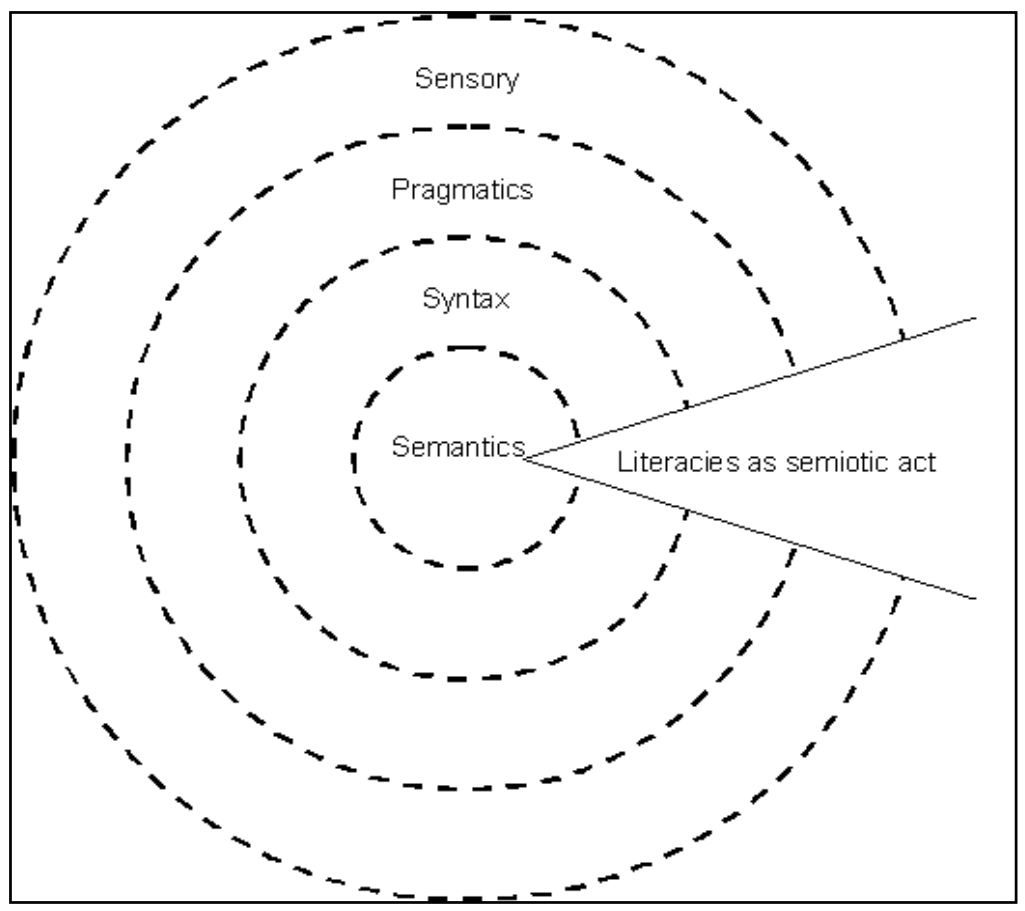

Figure 7: Basic literacies model (modified from Harste, et al., 1984)

literacies and the meaning a literacies user brings to the text. Whenever we engage in any literate act we are trying to make sense of it. Meaning making is a semiotic process, and the interpretation, or translation, of literacies into meaning is just as dependent on what a person brings to the construction of a literate act as the product itself. Meaning, then, is something that is mediated by each person and interpreted differently based on his or her experiences, discourse, and location, in what Louise Rosenblatt termed transaction theory (1989). Meaning is inherently related to the lived experience of the literacies user (Sumara, 1996; 1999) or the context within which the literacies use is being conducted. For example, Tristan uses his past experiences playing videogames and all of the information presented to him when he is playing a videogame to game to make sense of the game and excel at it.

Another piece of the literacies process is the sensory cueing system. The sensory cuing system is the way in which we interact with and perceive a literacy; this is typically the one area in which literacies are divergent. The way Simon makes meaning while he is drawing is different from the way he makes meaning while he is writing, which is different from the way he makes meaning while he is reading. This confuses some people into believing the sensory cuing system is the only cueing system because it often defines the 'uniqueness' of a literacy. The literacies user interacts with different literacies using different combinations of senses, and it is this, combined with purpose, that makes literacies different and creates multiple literacies. Without this 'uniqueness' there would be no need for different literacies; each literacy conveys meaning and is understood differently. 
When understanding a literacy we also apply syntax, or rules, to the literacy. It is these rules that help us understand a literate act; it is this cueing system which gives literacies order and predictability. Admittedly the rules are more or less rigid depending on the literacies being used; for example the rules in modern dance are more flexible than in classical ballet and the syntax for written language is more rigid than for spoken language. That said, all literacies are rule driven, even when it seems to an outsider that there are no rules. It is Tristan's exploitation of the rules of a videogame that make him such a proficient gamer.

Finally, we are always using pragmatics to make meaning from a literate act. Pragmatics is the context within and around a literate act. Pragmatics on one level can be thought of as the context a literacy event occurs in; it is everything that has happened up to that particular moment and everything that is going to come after. Pragmatics engages the literacies user's past experiences with the particular literacy to help make meaning out of the current literacy event. So not only are you relying on the particular book you are reading, but also your knowledge and experiences with reading in general; added to this is your experience with reading a particular genre or author. Pragmatics is also the experiences a literacies user brings to the literacies event to make meaning. Your understanding and knowledge of the particular content being discussed in the book influence your understanding of the text. Emily used her knowledge of dance and The Nutcracker to make sense of the increasingly difficult texts she was borrowing from the library, and in the case of the coffee table books was able to use the pictures as a support to help further her understanding.

We use these four cuing systems: semiotic, syntactic, sensory, and pragmatic within a semiotic discourse to make sense of any literate event. My children have shown me that when literacies are working together and we allow the overlap of learning, it is easier for us to understand and make sense of a literate event. The cueing systems in each of the literacies being used scaffold each other to support learning and understanding (see figure 9). Also, as we add more literacies our chances of having our message understood by others or understanding a message ourselves increases significantly. Each of the literacies scaffolds our understandings, and working together they assist the meaning making process, as has been demonstrated by each of the children's stories.

\section{Conclusions}

Emily, Tristan and Simon used different literacies to define who they were and to construct a literate identity. They each engaged with literacies in powerful and life transforming ways. They did not emulate their siblings, but instead seemed compelled to find a way to distinguish themselves as individuals. Literacies allowed the children to do this through what Michelle Knobel and Colin Lankshear refer to as the Ethos of a literacy (2007). Knobel and Lankshear are referring to the new ethos, or way of being, that new literacies make available for literacies users and which does a good job of describing how Tristan takes on the ethos of a gamer when he engages with videogames 
as a literate practice. But this idea of ethos I think goes beyond the new literacies. Each of the children used different literacies to explore ways of understanding and being in the world: Emily became a dancer and a reader, Tristan became a gamer and reader, Simon became an artist and a writer. These literacies allowed the children new ways to be in the world and with which to construct their identity.

The children also used multiple literacies together to help them learn, understand and create meaning more fully. Each used their motivated interest in a preferred literacy to access other literacies. Emily used dance to more fully become a reader; Tristan used his interest and experience with videogaming to see himself as a member of the literacy club and to access reading as a literacy; Simon used drawing as a way of exploring reading and writing. Using literacies they were precocious at, they scaffolded their learning of another literacy -in each of their cases a traditional literacy.

The learning of these traditional literacies was not accidental or learned through happenstance. Reading and writing, more than any other literacy, are emphasized and used throughout our society. They are the primary ways we communicate, making experiences with reading and writing more frequent than any other. The children were literally bombarded with meaningful purposes for using and having to understand reading and writing. In fact, it seems the use and understanding of these conventional literacies by Emily, Tristan, and Simon was unavoidable because of their pervasive nature within our society. The fears of those who think that schools are not emphasizing these literacies enough and that children will not be able to function within society without a great deal of direct and explicit instruction in reading and writing are misplaced. With the exception of Emily, my children explored the use and understanding of these conventional literacies without any formal instruction. The children were best able to use and understand the conventional literacies of writing and reading when they used other literacies as supports, had authentic reasons for using these literacies, were supported by each other, were supported by Christine and me, and were immersed in a society where the use of these literacies was ubiquitous.

My children have taught me that we need to broaden our definition of literacies and that we need to value multiple and new literacies, not just reading and writing, and accept and value home and out of school literacies. Literacy is so much more than decoding the words on a page. My children helped me see that we need to treat literacies as complex, and create situations where multiple literacies can emerge. We need to help children make connections between new, multiple, and traditional literacies within these contexts. We need to value children as capable, powerful, and successful literacies users. But most of all my children have taught me that I need to relax and trust them, valuing the literacies they are using right now.

When we understand literacies as complex and through the lens of complex systems theory we get better understand of how literacies emerge. All complex systems have certain features that apply to and help explain literacies in their use, understanding and learning. In attempting to analyze the whole of literacies for my children I was able to see the complex interactions among its subunits and better understand literacies as a process. We need to think of literacies as complex while simultaneously treating 
literacies as multimodal, semiotic, social, discourse dependant, and imbedded in specific practices.

The evidence from my children suggests that we still have much to learn. This study needs to be broadened to take into account the voices of children from different discourses. We need to see if, as I believe, the direction suggested by my children is not unique to our situation, but is something that is common to more $\mathrm{D} /$ discourses. We need to reconsider what we thought we knew and believed about literacies, and embrace complexity, thereby gaining deeper insight in order to better support our children in their literate lives.

\section{References}

Alcott, L. (1995/1868). Little women. Leicester, UK: Charnwood.

Baghban, M. (2002). Sisters and brothers reading together: An untapped resource into literacy. Lanham, MD: University Press of America.

Bissex, G. (1980). GNYS AT WRK: A child learns to write and read. Cambridge, MA: Harvard University Press.

Britzman, D. (1997). The tangles of implication. Qualitative Studies in Education, 10(1), 31-37.Browne, A. (1998). Voices in the park. New York, NY: DK Publishing Inc.

Burke, C. (2000). L540: Methods of teaching reading. Course taught at Indiana University, Bloomington, Indiana.

Carspecken, P. (1996). Critical ethnography in educational research: A theoretical and practical guide. New York, NY: Routledge.

Camazine, S. (2003) Patterns in nature. Natural History June, 03.

Browne, A. (1998). Voices in the park. New York, NY: DK Publishing Inc.

Carspecken, P. (1996). Critical ethnography in educational research: A theoretical and practical guide. New York, NY: Routledge.

Colman, E. (1996). White socks only. New York: Albert Whitman \& Co.

Creswell, J. (1994). Research design: Qualitative \& quantitative approaches. Thousand Oaks, CA: Sage Publications.

Crews, D. (1978). Freight train. New York: Harper Collins Publishing.

Danesi, M. (1998). Sign, thought, and culture. Toronto: Canadian Scholars' Press.

Danesi, M. (2004). Messages and meanings: An introduction to semiotics. Toronto, ON: Canadian Scholars' Press inc.

Denzin, N. (1997). Interpretive ethnography: Ethnographic practices for the $21^{\text {st }}$

century. Thousand Oaks, Ca: Sage Publications.

de Saint-Exupnt-, A. (1943). The little prince. Orlando, FL: Harcourt Brace \& Company.

Doake, D. (1988). Reading begins at birth. Richmond Hill, ON: Scholastic Canada Ltd.

Gallas, K. (1998). The languages of learning: How children talk, write, dance, draw and sing their understanding of the world. New York, NY: Teachers College Press.

Gee, J. (2003). What video games have to teach us about learning and literacy. New York, NY: Palgrave Macmillan.

Goodman, K. (1967). Reading: A psycholinguistic guessing game. Journal of the Reading Specialist. 6:126135.

Hamilton, M. (2000). Expanding the new literacy studies. In D. Barton, M. Hamilton \& R, Ivanil (eds). Situated literacies. New York, NY: Routledge.

Harste, J., Woodward, V., \& Burke, C. (1984). Language stories and literacy lessons. Portsmouth, NH: Heinemann. 
Heath, S. (1983). Ways with words: Language, life, and work in communities and classrooms. Cambridge, UK: Cambridge University Press.

Hoffman, M. (1991). Amazing grace. Parsippany, NJ: Scott Foresman.

Knobel, M. \& C. Lankshear (Eds). (2007). The new literacies sampler. New York: Peter Lang.

Lather, P. (1992). Critical frames in educational research: Feminist and $p$ poststuctural perspectives. Theory into Practice,31(2), 1-13.

Lorbiecki, M. (1996). Just one flick of a finger. New York, NY: Penguin Putnam Books for Young Readers. Lorbiecki, M. \& Popp, W. (1998). Sister Anne's hands. New York, NY: Dial Books for Young Readers.

Lowe, O. (1924). The Arabian Nights. London: The John C. Winston Company.

Luke, A. \& Freebody, P. (1997). Shaping the social practices of reading. In S. Muspratt, A. Luke, \& P. Freebody (Eds.), Constructing critical literacies: Teaching and learning textual practice. (pp. 185-225). Cresshill, NJ: Hampton Press.

Martens, P. (1996). i already know how to read: A childddldhing and learni. Portsmouth, NH: Heinemann.Muspratt, S., A. Luke, \& P. Freebody (Eds). (1997). Constructing critical literacies: Teaching and learning textual practice. Cresskill, NJ: Hampton Press.

Nintendo. (1999). Super Mario Bros. Deluxe. Redmond, Washington: Nintendo of America Inc.

Paley, V. (1999). The Kindness of Children. Cambridge, MA: Harvard University Press.

Paley, V. (2000). White teacher. Cambridge, MA: Harvard University Press.

Phinney, M. (1998). Reading with the Troubled Reader. Portsmouth, NH: Heinemann.

Piaget, J. (1971). Psychology and epistemology. New York, NY: Grossman.

Rosenblatt, L. (1989). Writing and reading: The transactional theory. Reading and Writing Connections, 153-176. Boston: Allyn and Bacon.

Rowe, D. (2005). What have we learned since language stories and literacy lessons? The potentials of reframing early literacy learning as social practice. Presentation, Researching and Teaching Language in these Critical Times. Bloomington, Indiana.

Schickedanz, J. (1990). Adam (1990). Indiana.ing and Teaching Language in these Critical Times. Bloomington, Indian. Portsmouth, NH: Heinemann.

Shange, N. (1997). Whitewash. New York: Walker and Company.

Shannon, P. (1995). Text, lies and videotape. Portsmouth, NH: Heinemann.

Short, K., Harste, J., Burke, C. (1996). Creating classrooms for authors and inquirers. Portsmouth, NH: Heinemann.

Sumara, D. (1996). Private readings in public: Schooling the literary imagination. New York: Peter Lang Publishing, Inc.

Sumara, D. (1999). Developing literary anthropologies with queer subjects. Presentation, National Reading Conference, Orlando, Florida.

Taylor, D. (1993). From the child's point of view. Portsmouth, NH: Heinemann Educational Publishers.

Tennant, V. (1979). On stage please. Toronto, ON: Tundra Books.

Tolkien, J. (1937/1999). The hobbit. New York, NY: Houghton Mifflin.

Vasquez, V. (2004). Negotiating critical literacies with young children. Hillsdale, NJ: Lawrence Erlbaum Associates.

Vygotsky, L. (1978). Mind in society. Cambridge: Harvard University Press.

Wood, J. (2002). Defining literacies. New Orleans, LA: Annual Meeting of the American Educational Research Association (ERIC Document Reproduction Service No. ED 465980).

\section{Acknowledgments}

I would like to thank Emily, Tristan and Simon for their patience and all they have taught me. And I would like thank Dr. Jerry Harste, Dr. Carolyn Burke and Dr. Vivian Vasquez for their guidance and support while I was conducting this research. 


\begin{abstract}
About the Author/s
Jeffrey Wood is an assistant professor in the Faculty of Education at Laurentian University. His research interests include: new/multiple literacies, early childhood education and critical literacies. Jeffrey can be contacted at jwood@laurentian.ca.

(c) Copyright 2015. The author, Jeffrey Wood, assigns to the University of Alberta and other educational and non-profit institutions a non-exclusive license to use this document for personal use and in courses of instruction provided that the article is used in full and this copyright statement is reproduced. The author also grants a non-exclusive license to the University of Alberta to publish this document in full on the World Wide Web, and for the document to be published on mirrors on the World Wide Web. Any other usage is prohibited without the express permission of the author.
\end{abstract}

